\title{
UJI EFEKTIVITAS EKSTRAK ETANOL RIMPANG TEMULAWAK TERHADAP PENURUNAN KADAR GLUKOSA DARAH PADA MENCIT
}

\author{
Nasdiwaty Daud \\ Jurusan Farmasi Poltekkes Kemenkes Medan
}

\begin{abstract}
Abstrak
Diabetes mellitus adalah penyakit metabolisme yang ditandai dengan tingginya kadar glukosa di dalam darah. Indonesia menduduki peringkat ke-4 penderita diabetes mellitus di dunia setelah Amerika Serikat, India dan China. Banyak tumbuhan yang dapat dijadikan alternative sebagai obat diabetes, salah satunya adalah temulawak (Curcuma xanthorrhiza Roxb). Penelitian ini bertujuan untuk mengetahui efektivitas ektrak etanol rimpang temulawak terhadap penurunan kadar gllukosa darah dan kadar yang paling efektif dalam menurunkan kadar glukosa darah. Jenis penelitian yang digunakan adalah penelitian eksperimental, dimana hewan uji yang digunakan adalah 18 ekor mencit, yang terbagi dalam 6 kelompok dan masingmasing kelompok terdiri dari 3 ekor mencit. Kelompok 1 diberikan aquadest, kelompok 2 diberikan CMC 0,5\%, kelompok 3 diberikan suspensi metformin 65 mg / Kg BB, kelompok 4 diberikan ekstrak etanol rimpang temulawak dosis 0,5 g / Kg BB, kelompok 5 diberikan ekstrak etanol rimpang temulawak dosis $1 \mathrm{~g}$ / Kg BB, kelompok 6 diberikan ekstrak etanol rimpang temulawak dosis 2 g / Kg BB. Kadar glukosa darah diperiksa setiap 15 menit selama 2 jam setelah pemberian glukosa $1 \mathrm{~g} / \mathrm{Kg}$ BB secara oral. Hasil dari penelitian menunjukkan penurunan kadar glukosa darah yang disebabkan oleh pemberian ekstrak etanol rimpang temulawak dosis 0,5 g / Kg BB, $1 \mathrm{~g} / \mathrm{Kg}$ BB dan $2 \mathrm{~g}$ / Kg BB. Ekstrak etanol rimpang temulawak 2 $\mathrm{g} / \mathrm{Kg}$ BB lebih efektif dalam menurunkan kadar glukosa darah daripada ekstrak etanol rimpang temulawak dengan dosis 0,5 g/ Kg BB dan $1 \mathrm{~g} / \mathrm{Kg}$ BB serta mempunyai efek yang hampir sama dengan metformin.
\end{abstract}

Kata Kunci : Diabetes mellitus, Ekstrak etanol rimpang temulawak, Metformin

\section{PENDAHULUAN}

Diabetes atau kencing manis adalah penyakit metabolisme yang ditandai dengan tingginya kadar glukosa dalam darah, penyakit ini juga sering disebut "the great imitator" karena dapat menyerang semua organ tubuh dan menimbulkan berbagai keluhan. Penyakit ini timbul perlahan-lahan sehingga seseorang tidak menyadari berbagai perubahan dalam dirinya. Selain karena memang adanya faktor keturunan, diabetes juga bisa dipicu pola makan yang tidak sehat. Bahkan, faktor utama penyebab diabetes lebih besar disebabkan karena pola makan yang tidak sehat yakni pola makan yang tinggi karbohidrat disertai dengan konsumsi makanan siap saji yang sarat kalori karena terlalu berlemak dan banyak mengandung kadar gula, serta gerak fisik yang minim dilakukan. (Depkes RI, 2010)

Jumlah penderita diabetes meningkat setiap tahunnya. Berdasarkan data Organisasi Kesehatan Dunia (WHO) penderita diabetes di Indonesia diperkirakan akan mengalami kenaikan dari 8,4 juta jiwa pada 2000, menjadi 21,3 juta jiwa pada 2030. Tingginya angka kesakitan tersebut, menjadikan Indonesia menduduki ranking ke-4 dunia, setelah Amerika Serikat, India dan Cina. Selain itu, hasil Riset kesehatan Dasar (Riskesdas) tahun 2007, diperoleh bahwa proporsi penyebab kematian akibat Diabetes
Mellitus pada kelompok usia 45-54 tahun di daerah perkotaan menduduki ranking ke-2 yaitu 14,7\% dan daerah pedesaan, DM menduduki ranking ke-6 yaitu $5,8 \%$.

Kemajuan teknologi telah banyak mengangkat pengobatan tradisional ke forum ilmiah sehingga pemanfaatan tumbuhan sebagai obat semakin diteliti dan dijadikan sebagai salah satu metode pengobatan alternatif, sekaligus menjadi pilihan yang cukup bijaksana di tengah maraknya obat kimia dibanding obat tradisional. Banyak tumbuhan yang dijadikan alternatif sebagai obat diabetes mellitus, salah satunya adalah temulawak.

Obat tradisional sudah dikenal masyarakat sejak zaman dahulu. Pengobatan dengan menggunakan obatobatan tradisional juga merupakan alternatif dalam bidang pengobatan. Menurut Undang-Undang Republik Indonesia tentang Kesehatan disebutkan bahwa yang dimaksud dengan obat tradisional adalah bahan atau ramuan bahan yang berupa bahan tumbuhan, bahan hewan, bahan mineral, sediaan sarian (galenik) atau campuran dari bahan tersebut, yang secara turun temurun telah digunakan untuk pengobatan dan telah diterapkan sesuai dengan norma yang berlaku di masyarakat.

Temulawak memiliki khasiat sebagai antidiabetes. Pemanfaatan temulawak sebagai obat diabetes mellitus telah banyak dilakukan oleh masyarakat di Dusun IV Aek Song-songan, Asahan dan Jawa Tengah. Selain dapat 
dimanfaatkan sebagai obat, temulawak juga dimanfaatkan sebagai sumber karbohidrat, bahan penyedap masakan dan minuman, serta pewarna alami untuk makanan dan kosmetika. Bagian yang paling banyak dimanfaatkan adalah rimpangnya. Khasiat Temulawak telah banyak diketahui berdasarkan pengalaman empiris dan hasil penelitian. Rimpang temulawak memiliki banyak khasiat, antara lain sebagai analgetik, anthelmintik, anti bakteri dan anti fungi, antidiabetik, antihepatotoksik, anti inflamasi, anti oksidan, anti tumor, penekan saraf pusat, diuretika, hipolipidemik, hipotermik, insektisida dan lain-lainnya. (Sina, 2013)

Fitofarmaka adalah sediaan obat bahan alam yang telah dibuktikan keamanan dan khasiatnya secara ilmiah dengan uji praklinik dan uji klinik, bahan baku dan produk jadinya telah distandarisasi. Fitofarmaka harus memenuhi criteria sebagai berikut: aman sesuai dengan persyaratan yang telah ditetapkan, klaim khasiat dibuktikan berdasarkan uji klinik, telah dilakukan standarisasi terhadap bahan baku yang digunakan dalam produk jadi dan memenuhi persyaratan mutu berlaku.Jenis klaim penggunaan sesuai dengan tingkat pembuktian yaitu tingkat pembuktian medium dan tinggi.

Dalam penelitian ini, peneliti menggunakan rimpang temulawak yang kering dalam bentuk ekstrak. Hal ini dilakukan untuk menghindari efek samping karena temulawak memiliki kandungan tepung yang cukup besar, sehingga ketika menggunakan perasan air temulawak mentah (tidak direbus atau diseduh dengan air panas), maka perasan tersebut harus diendapkan dahulu supaya tepungnya tidak ikut terminum karena tepung mentah dapat mengganggu fungsi ginjal. Dasar pemilihan dosis disesuaikan dengan dosis yang digunakan masyarakat dalam bentuk rebusan. Untuk melihat sejauh mana efek ekstrak etanol rimpang temulawak (Curcuma xanthorriza Roxb) terhadap penurunan kadar glukosa darah, peneliti menggunakan Metformin sebagai pembandingnya.

\section{PERMASALAHAN}

Rumusan masalah dalam penelitian ini adalah apakah ekstrak etanol rimpang temulawak (Curcuma xanthorrhiza Roxb) mempunyai efek penurunan kadar glukosa darah dan berapakah kadar ekstrak etanol yang paling efektif dalam menurunkan kadar glukosa darah

\section{TUJUAN PENELITIAN}

Tujuan penelitian ini antara lain untuk membuktikan efektivitas ekstrak etanol rimpang temulawak sebagai penurun kadar glukosa darah dan mengetahui kadar ekstrak etanol rimpang temulawak yang paling efektif dalam menurunkan kadar glukosa darah.

\section{MANFAAT PENELITIAN}

Adapun manfaaat penelitian ini yaitu untuk memberikan informasi kepada masyarakat khususnya penderita diabetes mellitus tentang pemanfaatan rimpang temulawak (Curcuma xanthorrhiza Roxb) sebagai penurun kadar glukosa darah. Bagi akademis, gagasan ini dapat mendorong dan mengkaji lebih lanjut untuk memformulasikan sediaan yang mengandung temulawak, tidak hanya untuk penyakit diabetes. Serta untuk pengembangan bidang kesehatan dengan memanfaatkan obat-obat tradisional dan bahan alam.

\section{METODE PENELITIAN}

\section{Jenis Penelitian}

penelitian ini adalah metode eksperimental yaitu dengan menguji ekstrak etanol rimpang temulawak terhadap penurunan kadar gukosa darah dengan mencit (Mus musculus) sebagai hewan percobaan

\section{Lokasi dan Waktu Penelitian}

Penelitian dilakukan di laboratorium farmakologi Jurusan Farmasi Poltekkes Kemenkes Medan. Penelitian dilakukan selama 2 minggu.

\section{Populasi dan Sampel}

Populasi penelitian ini adalah rimpang temulawak yang diperoleh di sekitar perumahan masyarakat di Jalan Binjai Km 13,8 P. Besar, Sei Semayang, Kecamatan Sunggal. Sampel yang diuji pada penelitian ini adalah rimpang temulawak segar yang akan dikeringkan. Sampel diambil secara purposive sampling yaitu pengambilan sampel tanpa mempertimbangkan tempat dan letak geografisnya dengan kriteria yang ditentukan sendiri yaitu rimpang temulawak diambil dari tanaman yang siap panen yaitu memiliki daun-daun dan bagian tanaman yang telah menguning dan mengering dan memiliki rimpang besar serta berwarna kuning kecoklatan.

\section{Hewan Percobaan}

Hewan percobaan yang digunakan adalah mencit (Mus musculus) dengan kondisi sehat yang diperoleh di peternakannya. Jumlah mencit yang digunakan sebanyak 18 ekor dengan berat 20-30 g. Persiapan hewan percobaan sebagai berikut :

a. Pembuatan dan pembersihan kandang

Kandang mencit dibuat sebanyak 6 buah yang terbuat dari kayu dengan dinding atas dibuat dari kawat kasa. Kandang kemudian dibersihkan.

b. Penempatan mencit

Setelah kandang dibersihkan, mencit diberi nomor pada ekornya kemudian dimasukkan ke dalam kandang masing-masing 3 ekor.

c. Adaptasikan mencit selama 1 minggu, beri makanan dan minuman yang baik serta lingkungan yang baik.

d. Sebelum digunakan untuk percobaan, puasakan mencit (hanya diberi air minum saja) selama 12 jam.

e. Beri kode pada tiap-tiap mencit yang akan digunakan. 


\section{Alat dan Bahan}

Alat yang digunakan dalam penelitian ini adalah beaker glass, batang pengaduk, cawan penguap,gelas ukur, glukometer, jarum suntik $1 \mathrm{ml}$, kayu dan kain penyaring, lumpang dan stamper, neraca Analitik, oral needle $1 \mathrm{ml}$, panci ekstrak, plastik dan karet, strip cek gula darah dan timbangan. Sementara bahan yang digunakan adalah Alkohol 96\%, aquadest, ekstrak etanol rimpang temulawak, CMC 0,5\% dan metformin.

\section{Pembuatan Simplisia Rimpang Temulawak}

Timbang sejumlah tertentu rimpang temulawak yang masih segar, dicuci bersih dengan air kemudian tiriskan. Rimpang temulawak diiris tipis-tipis lalu dikeringkan pada suhu rendah di luar matahari langsung.

\section{Pembuatan Ekstrak Rimpang Temulawak}

Pada penelitian ini pembuatan ekstrak rimpang temulawak dilakukan dengan cara maserasi menggunakan alkohol 96\%. Ekstrak dibuat sesuai ketentuan Farmakope Indonesia edisi III, masukkan 10 bagian rimpang temulawak yang telah dikeringkan ke dalam sebuah wadah, tuangi dengan 75 bagian etanol 96\%, tutup, biarkan selama 5 hari terlindung dari cahaya matahari sambil sering diaduk, serkai, peras cuci ampas dengan etanol 96\% secukupnya hingga diperoleh 100 bagian. Pindahkan ke dalam wadah tertutup, biarkan di tempat sejuk, terlindung dari cahaya, selama 2 hari. Enap tuangkan atau saring.

Kemudian maserat diuapkan pada suhu rendah yaitu pada suhu $\pm 40^{\circ} \mathrm{C}$ dengan menggunakan alat rotary evaporator hingga diperoleh ekstrak kental rimpang temulawak, kemudian keringkan.

\section{Pembuatan Pensuspensi 0,5\%}

Sebanyak 0,5 g CMC (Carboxyl Methyl Celulose) ditaburkan ke dalam lumpang yang telah berisi aquadest panas sebanyak $20 \mathrm{ml}$, biarkan selama 15 menit sehingga diperoleh massa yang transparan, setelah mengembang digerus lalu diencerkan dengan sedikit aquadest. Kemudian dimasukkan ke dalam wadah, cukupkan dengan aquadest hingga $100 \mathrm{ml}$.

\section{Pembuatan Suspensi Ekstrak etanol Rimpang Temulawak}

Pemberian rimpang temulawak sebagai penurun kadar glukosa darah dalam kehidupan sehari-hari diberikan dalam bentuk minuman yang dibuat dengan 25 g rimpang temulawak dalam $300 \mathrm{ml}$ air panas.

100 g rimpang temulawak kering menghasilkan ekstrak kental sebanyak 33,01 g

Dosis ekstrak rimpang temulawak pada manusia $=\frac{25 \mathrm{~g}}{100 \mathrm{~g}}$ $\times 33,01 \mathrm{~g}=8,25 \mathrm{~g}$

Konversi untuk mencit $(20 \mathrm{~g})=0,0026$.

Dosis ekstrak rimpang temulawak untuk mencit $=8,25 \mathrm{~g} \mathrm{x}$ $0,0026=0,021 \mathrm{~g}$.

Dosis per $\mathrm{KgBB}=\frac{1000 \mathrm{~g}}{20 \mathrm{~g}} \times 0,021 \mathrm{~g}=1 \mathrm{~g} / \mathrm{Kg} \mathrm{BB}$
Maka, kadar Ekstrak Etanol Rimpang Temulawak yang diujikan adalah:

Kadar I $=\frac{1}{2} \times 1 g / K g B B=0,5 g / K g B B$.

Timbang 0,5 g EERT, kemudian suspensikan dalam CMC $0,5 \%$ ad $10 \mathrm{ml}$.

Dosis untuk mencit $20 \mathrm{~g}=\frac{20 \mathrm{~g}}{1000 \mathrm{~g}} \times 0,5 \mathrm{~g} / \mathrm{Kg} \mathrm{BB}=0,010$ $\mathrm{g} / \mathrm{Kg}$ BB.

Maka volume pemberian $=\frac{0,010 \mathrm{~g}}{0,5 \mathrm{~g}} \times 10 \mathrm{ml}=0,2 \mathrm{ml}$

Kadar II = 1 g / Kg BB.

Timbang 1 g EERT, kemudian suspensikan dalam CMC $0,5 \%$ ad $10 \mathrm{ml}$.

maka dosis untuk mencit $20 \mathrm{~g}=\frac{20 \mathrm{~g}}{1000 \mathrm{~g}} \times 1 \mathrm{~g}=0,02 \mathrm{~g} / \mathrm{Kg}$ BB.

Maka volume pemberian $=\frac{0,02 \mathrm{~g}}{1 \mathrm{~g}} \times 10 \mathrm{ml}=0,2 \mathrm{ml}$

Kadar III = 2 x 1 g $/$ Kg BB $=2$ g $/$ Kg BB.

Timbang 2 g EERT, kemudian suspensikan dalam CMC $0,5 \%$ ad $10 \mathrm{ml}$

maka dosis untuk mencit $20 \mathrm{~g}=\frac{20 \mathrm{~g}}{1000 \mathrm{~g}} \times 2 \mathrm{~g}=0,04 \mathrm{~g} / \mathrm{Kg}$ BB.

Maka volume pemberian $=\frac{0,04 \mathrm{~g}}{2 \mathrm{~g}} \times 10 \mathrm{ml}=0,2 \mathrm{ml}$

\section{Pembuatan larutan Glukosa}

Glukosa yang digunakan adalah $10 \%$ dengan dosis $1 \mathrm{~g} /$ $\mathrm{Kg}$ BB.

Konversi untuk mencit $(20 \mathrm{~g})=0,0026$.

Dosis glukosa untuk mencit $=\frac{20}{1000} \times 1 \mathrm{~g}=0,02 \mathrm{~g}$

Timbang $10 \mathrm{~g}$ glukosa larutkan dengan aquadest sampai $100 \mathrm{ml}$.

Maka,dosis pemberian larutan glukosa untuk $20 \mathrm{~g}$ mencit $=\frac{0,02 \mathrm{~g}}{10 \mathrm{~g}} \times 100 \mathrm{ml}$ $=0,2 \mathrm{ml}$

\section{Pembuatan Suspensi Metformin}

Dosis Metformin untuk manusia (dewasa) adalah $500 \mathrm{mg}$.

Konversi untuk mencit $20 \mathrm{~g}=0,0026$

Maka dosis untuk mencit bobot $20 \mathrm{~g}=500 \mathrm{mg}$ x 0,0026

$$
=1,3 \mathrm{mg}
$$

Dosis per $\mathrm{KgBB}=\frac{1000 \mathrm{~g}}{20 \mathrm{~g}} \times 1,3 \mathrm{mg}=65 \mathrm{mg} / \mathrm{Kg} \mathrm{BB}$

Sediaan metformin adalah $500 \mathrm{mg} / \mathrm{tab}$.

Bobot 1 tablet $=550 \mathrm{mg}$.

Untuk $100 \mathrm{mg}$ Metformin $=\frac{100 \mathrm{mg}}{500 \mathrm{mg}} \times 550 \mathrm{mg}=110 \mathrm{mg}$.

Timbang $\infty 100 \mathrm{mg}$, Kemudian suspensikan dalam $10 \mathrm{ml}$ CMC 0,5\%

Volume yang akan diberikan pada mencit $20 \mathrm{~g}=\frac{1,3 \mathrm{mg}}{100 \mathrm{mg}}$ $\times 10 \mathrm{ml}=0,13 \mathrm{ml}$

Maka, volume suspensi Metmormin yang diberikan pada mencit sesuai berat badan adalah $\frac{\text { Berat mencit }(g)}{20 \mathrm{~g}} \times$ $0,13 m l=Y m l$. 


\section{Prosedur Kerja}

Pengambilan darah mencit dilakukan sebagai berikut: mencit dipegang punggungnya dengan perlakuan baik, kemudian ekor mencit dikeluarkan melalui jari kelingking dan jari manis. Bersihkan ekornya dengan alkohol 70\%, kemudian keringkan. Setelah kering, ambil darah mencit dari pembuluh darah ekor mencit dan darah diteteskan pada strip yang telah disediakan pada glukometer.

\section{Prosedur Percobaan}

a. Hewan percobaan dibagi dalam enam kelompok dan masing-masing kelompok terdiri dari tiga ekor mencit. Sebelum dilakukan percobaan, masingmasing kelompok ditimbang berat badannya dan diukur kadar glukosa darahnya sebagai kadar glukosa darah awal/normal. Puasakan semua mencit selama 12 jam sebelum dilakukan percobaan kemudian setiap mencit ditimbang berat badan puasa dan dilakukan pengukuran kadar glukosa darah puasa (KGDP).

b. Kelompok 1 (M1) diberikan aquadest sebagai kontrol, selanjutnya tiap 15 menit dilakukan pengukuran kadar glukosa darahnya sampai dua jam.

c. Kelompok 2 (M2) diberikan CMC 0,5 \%, tiga puluh menit kemudian diberikan larutan glukosa 1 g / Kg BB, selanjutnya tiap 15 menit dilakukan pengukuran kadar glukosa darahnya sampai dua jam. d. Kelompok 3 (M3) diberikan suspensi Metformin $65 \mathrm{mg} / \mathrm{Kg} \mathrm{BB}$, tiga puluh menit kemudian diberikan larutan glukosa $1 \mathrm{~g}$ / Kg BB, selanjutnya tiap 15 menit dilakukan pengukuran kadar glukosa darahnya sampai dua jam.

e. Kelompok 4 (M4) diberikan suspensi EERT 0,5 g / $\mathrm{Kg} \mathrm{BB}$, tiga puluh menit kemudian diberikan larutan glukosa $1 \mathrm{~g} / \mathrm{Kg} \mathrm{BB}$, selanjutnya tiap 15 menit dilakukan pengukuran kadar glukosa darahnya sampai dua jam.

f. Kelompok 5 (M5) diberikan suspensi EERT $1 \mathrm{~g} /$ $\mathrm{Kg} \mathrm{BB}$, tiga puluh menit kemudian diberikan larutan glukosa $1 \mathrm{~g} / \mathrm{Kg}$ BB, selanjutnya tiap 15 menit dilakukan pengukuran kadar glukosa darahnya sampai dua jam.

g. Kelompok 6 (M5) diberikan suspensi EERT 2 g / $\mathrm{Kg} \mathrm{BB}$, tiga puluh menit kemudian diberikan larutan glukosa 2 g / Kg BB, selanjutnya tiap 15 menit dilakukan pengukuran kadar glukosa darahnya sampai dua jam.

\section{HASIL PENELITIAN}

Dari hasil penelitian Uji Efektivitas Ekstrak Etanol Rimpang Temulawak (Curcuma xanthorrhiza Roxb) Terhadap Penurunan Kadar Glukosa Darah pada Mencit, didapat hasil sebagai berikut:

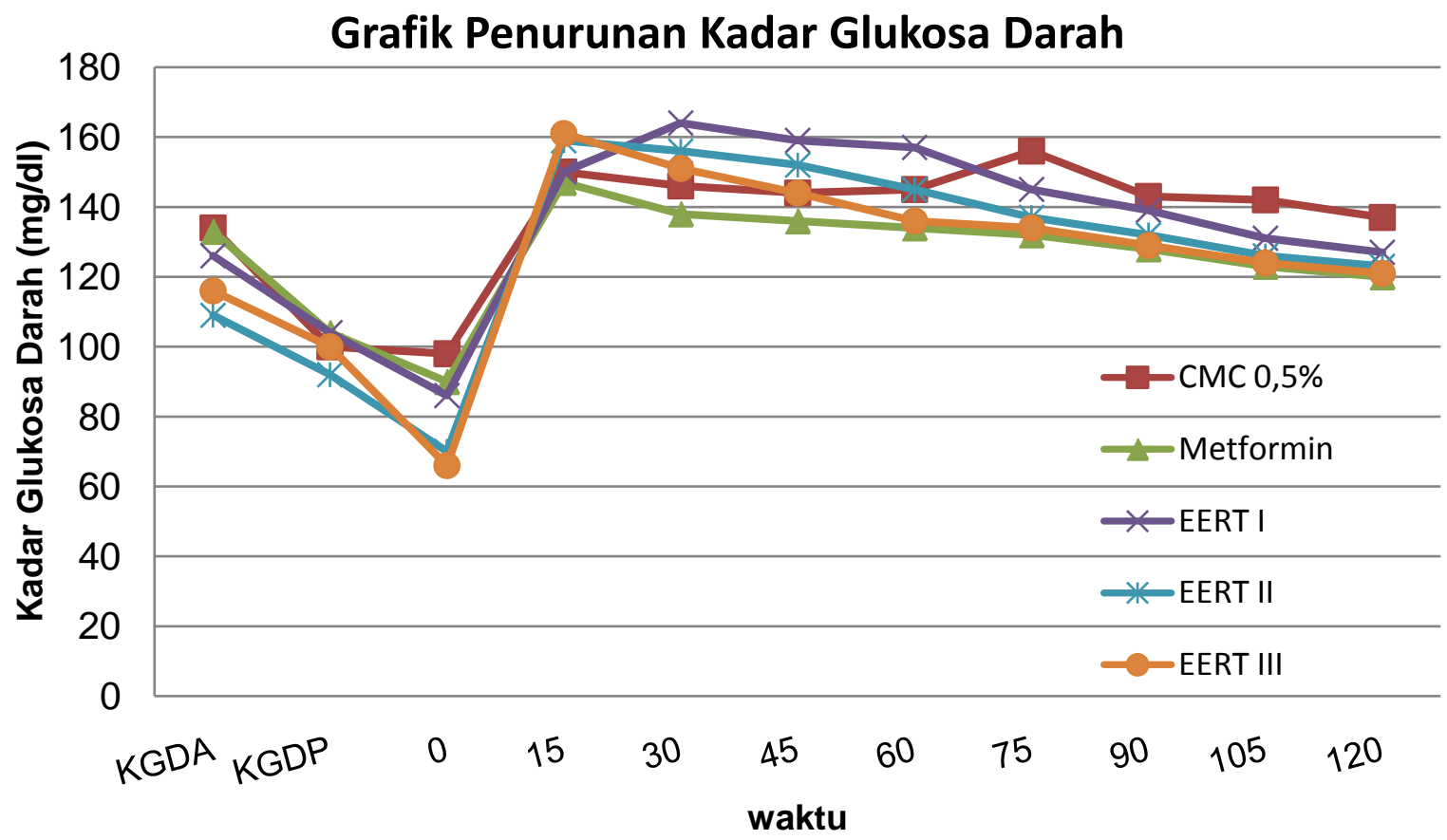




\section{PEMBAHASAN}

Kadar glukosa darah awal rata-rata kelompok M1 adalah 137,3 mg/dl, setelah dipuasakan menjadi 107,6 mg/dl. Kemudian diberi aquadest, setelah 30 menit kadar glukosa menjadi $104 \mathrm{mg} / \mathrm{dl}$. Kadar glukosa darah awal rata-rata kelompok M2 adalah $134 \mathrm{mg} / \mathrm{dl}$, setelah dipuasakan kadar glukosa darah menjadi 100,3 mg/dl. Setelah pemberian CMC 0,5\%, diberi larutan glukosa $1 \mathrm{~g} /$ Kg BB dan terjadi kenaikan kadar glukosa darah maksimal menjadi 150,3 mg/dl pada menit ke -15. Pada menit ke-90 kadar glukosa darah perlahan-lahan menurun namun tidak mencapai kadar glukosa darah normal. Hal ini menunjukkan bahwa CMC tidak mempunyai efek penurun kadar glukosa darah karena CMC hanya bahan tambahan dalam pembuatan suspensi.

Kadar glukosa darah awal rata-rata kelompok M3 adalah 133,3 mg/dl, setelah dipuasakan kadar glukosa darah menjadi $104 \mathrm{mg} / \mathrm{dl}$. Setelah pemberian suspensi Metformin, diberi larutan glukosa $1 \mathrm{~g}$ / Kg BB dan terjadi kenaikan kadar glukosa darah maksimal menjadi 146,6 $\mathrm{mg} / \mathrm{dl}$, namun pada menit ke-30 menunjukan penurunan kadar glukosa darah secara bertahap dan stabil mendekati normal yaitu $138 \mathrm{mg} / \mathrm{dl}$. Hal ini menunjukkan bahwa onset of action dari suspensi metformin adalah pada menit ke-30. Hal ini menyatakan bahwa Metformin sebagai obat hipoglikemik oral mampu menahan kenaikan kadar glukosa darah pada pemberian glukosa.

Kadar glukosa darah awal rata-rata kelompok M4 adalah 126,3 mg/dl, setelah dipuasakan kadar glukosa darah menjadi $104 \mathrm{mg} / \mathrm{dl}$. Setelah 30 menit pemberian suspensi EERT dosis 0,5 g / Kg BB, diberi larutan glukosa $1 \mathrm{~g} / \mathrm{Kg}$ BB dan terjadi kenaikan kadar glukosa darah maksimal menjadi $164 \mathrm{mg} / \mathrm{dl}$ pada menit ke-30, namun pada menit ke-45 menunjukan penurunan kadar glukosa darah secara bertahap dan stabil mendekati normal yaitu $159 \mathrm{mg} / \mathrm{dl}$. Hal ini menunjukkan bahwa onset of action dari suspensi ekstrak etanol rimpang temulawak dosis 0,5 g / Kg BB adalah pada menit ke- 45.

Kadar glukosa darah awal rata-rata kelompok M5 adalah 108,6 mg/dl, setelah dipuasakan kadar glukosa darah menjadi $92 \mathrm{mg} / \mathrm{dl}$. Setelah pemberian suspensi EERT dosis $1 \mathrm{~g} / \mathrm{Kg} \mathrm{BB}$, diberi larutan glukosa $1 \mathrm{~g} / \mathrm{Kg}$ BB dan terjadi kenaikan kadar glukosa darah maksimal menjadi 159,3 mg/dl pada menit ke-15, namun pada menit ke-30 menunjukan penurunan kadar glukosa darah secara bertahap dan stabil mendekati normal yaitu 155,6 mg/dl. Hal ini menunjukkan bahwa onset of action dari suspensi ekstrak etanol rimpang temulawak dosis $1 \mathrm{~g} / \mathrm{Kg} \mathrm{BB}$ adalah pada menit ke-30.

Kadar glukosa darah awal rata-rata kelompok M6 adalah 116,6 mg/dl, setelah dipuasakan kadar glukosa darah menjadi 100,3 mg/dl. Setelah pemberian suspensi EERT dosis 2 g / Kg BB, diberi larutan glukosa 1 g / Kg BB dan terjadi kenaikan kadar glukosa darah maksimal menjadi $161 \mathrm{mg} / \mathrm{dl}$ pada menit ke- 15, namun pada menit ke-30 menunjukan penurunan kadar glukosa darah secara bertahap dan stabil mendekati normal yaitu $1151 \mathrm{mg} / \mathrm{dl}$. Hal ini menunjukkan bahwa onset of action dari suspensi EERT dosis $2 \mathrm{~g}$ / Kg BB adalah pada menit ke-30.
Adanya perbedaan onset of action dari EERT 0,5 g / Kg BB, 1 g / Kg BB dan 2 g / Kg BB terhadap penurunan kadar glukosa darah disebabkan karena adanya kadar kurkuminoid pada EERT 2 g / Kg BB lebih banyak daripada EERT 0,5 g / Kg BB dan 1 g / Kg BB sehingga onset of action dari EERT $2 \mathrm{~g}$ / Kg BB lebih cepat daripada EERT 0,5 g / Kg BB dan $1 \mathrm{~g} / \mathrm{Kg}$ BB.

\section{SIMPULAN DAN SARAN}

\section{Simpulan}

Berdasarkan hasil pengamatan selama penelitian diperoleh beberapa simpulan sebagai berikut:

1. Suspensi EERT dengan dosis 0,5 g / Kg BB, 1 g / Kg BB dan 2 g / Kg BB mampu menahan kenaikan kadar glukosa darah pada mencit.

2. Semakin tinggi dosis yang diberikan maka efek penurunan kadar glukosa darah semakin cepat.

3. Suspensi EERT dengan dosis 2 g / Kg BB (kadar III) lebih efektif dalam menurunkan kadar glukosa darah daripada suspensi EERT dengan dosis $1 \mathrm{~g} /$ Kg BB (kadar II) dan suspensi EERT dosis 0,5 g / Kg BB (kadar I).

\section{Saran}

Disarankan kepada peneliti selanjutnya:

1. Meneliti khasiat lain dari rimpang temulawak.

2. Meneliti zat berkhasiat dari rimpang temulawak sebagai penurun kadar glukosa darah.

\section{DAFTARA PUSTAKA}

Anief, moh. Ilmu Meracik Obat. Universitas Gajah Mada: Yogyakarta.Hal:177-178

Dalimartha, setiawan. 2000. Atlas Tumbuhan Obat Indonesia Jilid 2. Jakarta: Trubus Agriwidya.Hal: 182-185.

Dalimartha, setiawan.1996. Ramuan tradisional untuk pengobatan Diabetes Mellitus. Jakarta: Penebar Swadaya.Hal: 8-10.

Departemen Kesehatan RI. 1979. Farmakope Indonesia Edisi III. Jakarta: Departemen Kesehatan RI. Hal: 32-33.

Departemen Kesehatan RI. 1995. Farmakope Indonesia Edisi IV. Jakarta. Hal: 268.

Departemen Kesehatan dan Kesejahteraan Sosial RI. 2000. Inventaris Tanaman Obat Indonesia I. Jilid Pertama. Bakti Husada. Jakarta. Hal: 85-86.

Departemen Kesehatan RI. 2005. "Pharmaceutical Care untuk Penyakit Diabetes Mellitus”. Jakarta: Direktorat Jendral Bina Kefarmasian dan Alat Kesehatan. Hal: 20-48.

Depkes RI, 2010. "Diabetes mellitus dapat dicegah” dari http://www.depkes.go.id/index.php/berita/pressrelease/1314-diabetes-melitus-dapat-dicegah.html diakses pada 20 Juni 2013

Info Diabetes Melitus. 2012. "Data Statistik Jumlah Penderita Diabetes Di dunia Versi WHO”. Diakses pada 20 Juni 2013, dari http://indodiabetes.com/data-statistik-jumlahpenderita-diabetes-di-dunia-versi-who.html 
Kompas. 2010. "Penderita Diabetes di Indonesia Meningkat”. Dari http://health.kompas.com/read/2010/05/29/2301343 9/Penderita.Diabetes.di.Indonesia.Meningkat yang diakses pada 20 Juni 2013

Laurence,B.Keith, P. Donald, B dan Lain. 2008. Goodman and Goldman's Manual of Farmacology and Therapeutics. Boston: Mc. Gran Hill. Hal: 620.

National Center for Complementary and Alternatif Medicine.2005.Treating Type 2 Diabetes with Dietary Supplements. http://nccam.nih.gov. [Juni 2013]

Republik Indonesia. 1992. Undang-Undang No. 761 Tahun 1992 tentang Pedoman Fitofarmaka. Jakarta : Sekretariat Negara.
Republika online. 2008. "Penderita diabetes 213 juta jiwa pada 2030”. Diakses pada 20 juni 2013 dari http://www.republika.co.id/berita/gaya-hidup/infosehat/08/11/14/13794-penderita-diabetes-21-3-jutajiwa-pada-2030.

Sina, yusuf. 2013. Sejuta Khasiat Herbal Temulawak: Penangkal Segala penyakit \& Penjaga Stamina Tubuh. Yogyakarta: Diandra Pustaka Indonesia.

Susanto, teguh. 2013. Diabetes, Deteksi, Pencegahan, Pengobatan. Jakarta: Buku Pintar. Hal: 23 -26

Tjay T.H dan Raharja K. 2006. Obat-Obat Penting: Khasiat, Penggunaan dan Efek-Efek Sampingnya. Cetakan Jakarta: PT Elex Media Komputindo. Hal: 739-742.

Vogel, H. 2008. Drug Discovery and Evaluation Edisi III. Berlin: Spinger. Hal: 1351. 